chairs, books in 24-point type, outline maps, heavy pencils, unglazed buff-coloured paper, typewriter and stand, material for handwork, correct natural and artificial lighting conditions, correct colour of walls and ceilings and matt finish for all surfaces." We consider that the institution of classes of this description by the various educational authorities would be of very great value, and would assist in setting the work of the school refractionist on a more satisfactory basis.

\title{
INTERNATIONAL CONGRESS OF OPHTHALMOLOGY
}

AT the recent Meeting of Delegates at Scheveningen the following Regulations and By-Laws were adopted:

\section{Regulations}

Article I.-The aim of the International Congress of Ophthalmology is to further the progress of Ophthalmolagy and to provide an opportunity of meeting and discussion for those interested in Ophthalmology.

Article II. - The general control 'of the Congress shall be in the hands of an International Council, elected at a general meeting of members of the Congress. It shall consist of a Chairman, a ViceChairman, a Treasurer, a Secretary and eight members and shall hold office until the end of the next succeeding Congress.

Article III.-The time and place of meetings of the Congress shall be considered by the Council and proposed to and decided by the general meeting of the Congress.

Article IV.-Membership of the Congress shall be limited (1) to the holders of diplomas in medicine, and (2) to those whom by reason of their scientific eminence in any of the allied sciences, or of their services to the cause of Ophthalmology, the Council may consider to be desirable members. The Council shall reserve the right of veto in the case of any applicant.

Article V.-The subscriptions for members and associates shall be fixed by the Council in collaboration with the National Committee.

Article VI.-Relatives and friends of members shall be eligible for election as associates on payment of a reduced subscription. They shall not take part in any of the scientific or business meetings of the Congress, but shall be entitled to be present at the social gatherings.

Article VII.-The local arrangements for each Congress shall be in the hands of a National Committee, selected by the Ophthalmologists of the country in which the Congress is to be held. 
The National Committee shall work in collaboration with the International Council.

Article VIII.- The President of the Congress shall be chosen by agreement between the International Council and the National Committee.

Article IX.-Secretaries, appointed by the National Committee, shall be responsible for keeping the minutes of the scientific meetings, for collecting the papers when read, and recording the discussions. They shall act as secretaries of the Editorial Committee.

Article X.-An Editorial Committee, appointed by the International Council, shall decide which papers are to be published in full and which in abstract, edit the discussions, and supervise in general the publication of the proceedings of each Congress.

Article XI.-A printed copy of the Transactions of the Congress shall be sent to each member.

Article XII.-The National Committee shall be responsible for the expenses of the Congress held under its auspices. After the business of the Congress is completed and the proceedings are published, it shall transmit audited and certified accounts to the International Council for filing in the archives of the Council. Any balance of funds after payment of all expenses shall be paid into the Council funds.

\section{By-Laws}

\section{Original Papers.}

(1) Any member desiring to read a paper must notify the subject and submit an abstract of the proposed paper to the Secretary not less than three months before the date of the Congress, so that it may be printed before the meeting.

(2) Abstracts shall contain only a summary of the main conclusions of the paper and shall be translated into at least three of the principal European languages.

(3) No communication which has already been published shall be read at the Congress.

(4) Ten minutes shall be allowed to the author for presentation of his subject and five minutes to each speaker in the discussion, (Members wishing to take part in the discussion shall submit their names in writing to the Chairman.)

(5) Speakers taking part in discussion of papers shall be respon'sible for preparing a summary of their remarks and giving it to the Editorial Secretary before the end of the meeting.

(6) All papers presented to the Congress shall be left in the care of the Secretary for submission to the Editorial Committee and, if accepted for printing, shall not be published elsewhere than in the 
Transactions of the Congress. If the Editorial Committee decide that the paper shall appear in abstract only, the writer may publish the full paper elsewhere.

(7) Reprints of papers appearing in the Transactions may be obtained by authors at their own expense from the printers, and must be ordered direct from the printers on receipt of the proofs.

\section{Symposia.}

(8) Subjects for symposia at each Congress shall be chosen by the Council who shall invite a limited number of speakers to introduce these discussions. The invited speakers shall each be allowed fifteen minutes. Each subsequent speaker in the symposia shall be allowed five minutes. By-law (5) shall also apply.,

\section{Demonstration of Cases and Specimens.}

(9) A special sitting of the Congress shall be devoted to the demonstration of cases, specimens, instruments, etc.

(10) All cases and specimens must be accompanied by a card giving the particulars intended for publication.

\section{OXFORD OPHTHALMOLOGICAL CONGRESS XVII ANNUAL MEETING}

THE Seventeenth Annual Meeting of the Oxford Ophthalmological Congress was held at Oxford on July 7, 8, and 9, under the Mastership of Mr. Philip H. Adams.

The proceedings took place in the Department of Human Anatomy through the kindness of Professor Arthur Thomson; whilst Keble College, where members met informally at dinner on July 6 , was again available for hospitality.

After a brief formal opening at 10 a.m. by the Master, a discussion was held on "The results of the Operative Treatment of Glaucoma." The opener, Dr. William H. Wilmer, Ophthalmologist-in-Chief to the Johns Hopkins Hospital, Baltimore; began with a reference to the work of von Graefe, who, in 1857, wrote concerning glaucoma "the absence of general agreement constitutes an hereditary evil of therapeutics only to be cured by slow degrees." - "The only treatment from which relief can be expected is one that diminishes pressure."

That both these propositions are true to-day is attested by the fact that over sixty operative procedures, with many modifications are on record, all of which are devised solely for the purpose of reducing intra-ocular tension. 